\title{
KELAS SOSIAL VS PENDAPATAN: \\ EKSPLORASI FAKTOR PENENTU PEMBELIAN CONSUMER GOODS DAN JASA
}

\author{
Anna Triwijayati dan Deviga Bayu Pradipta \\ Universitas Ma Chung Malang \\ anna.triwijayati@machung.ac.id dan deviga.bayu@gmail.com
}

\begin{abstract}
Social class and income influence consumer purchase behavior. This study aims to determine the relationship and difference between social class and income by purchasing consumer goods and services in Malang. This research used quantitative survey ex-post facto method. Research respondents were classified based on level of income and social class using the Index of Social Position (ISP). The quetionaire contaied 18 items of purchase, grouped into 5 types namely: food and drink, clothing, durable goods, investment, services and other products. Data analysis technique used chi-square. The results of the analysis show that the social class associate with the purchase of 17 items, while income associate with all items of goods and services consumed. Social class is more associated with fast food, clothes, electronic equipment, price and amount of investment and finance; income is more associated with meat, milk, the type of vehicle used, ownership of electronic tools, type of investment and finance, and housing and other buildings.
\end{abstract}

Keywords: social class, income, consumer goods and services, index of social position (ISP)

\begin{abstract}
Abstrak: Kelas sosial dan pendapatan berhubungan dengan perilaku pembelian. Penelitian ini menggunakan metode survey kuantitatif dengan pendekatan ex-post facto dan bertujuan untuk mengetahui hubungan dan perbedaan antara kelas sosial dan pendapatan dengan pembelian consumer goods dan jasa di Kota Malang. Responden diklasifikasikan berdasarkan tingkat kelas sosial dan pendapatan menggunakan Index of Social Position (ISP), selanjutnya mengisi kuesioner tentang 18 item pembelian yang dikelompokkan menjadi 5 jenis yaitu makanan dan minuman, pakaian, barang tahan lama, jasa investasi, dan produk lain-lain. Teknik analisis data menggunakan chi-square. Hasil analisis menunjukkan bahwa kelas sosial berhubungan dengan pembelian 17 item, sedangkan pendapatan berhubungan dengan seluruh item produk dan jasa yang dikonsumsi. Kelas sosial lebih berhubungan dengan fast food, baju, harga peralatan elektronik pribadi, dan jumlah investasi dan keuangan. Sedangkan pendapatan lebih berhubungan dengan daging, susu, jenis kendaraan yang digunakan, kepemilikan alat elektronik, jenis investasi dan keuangan, dan tempat tinggal dan bangunan lain
\end{abstract}

Kata-kata Kunci: kelas sosial, pendapatan, consumer goods and services, index of social position (ISP)

\section{PENDAHULUAN}

Kelas sosial dan pendapatan adalah bagian dari dua faktor eksternal yang mempengaruhi pembelian. Kedua faktor tersebut sering disatukan dan juga dipisahkan 
dalam kaitannya dengan perilaku pembelian. Dalam penelitian, kelas sosial dan pendapatan dapat mempengaruhi perilaku konsumen dalam kondisi yang berbeda. Penelitian klasik dari Myers, Stanton, \& Haug (1971), membandingkan korelasi antara kelas sosial dan pendapatan terhadap perilaku konsumen khusus pada barang-barang kebutuhan sehari-hari yang relatif murah. Penelitian ini menunjukkan bahwa pendapatan lebih dominan dalam mempengaruhi perlaku konsumen dalam kasus barang kebutuhan sehari-hari dalam bentuk kemasan dibandingkan kelas sosial. Kelas sosial itu sendiri lebih dominan dalam mempengaruhi produk-produk yang berhubungan dengan kenyamanan atau cara praktis seperti mie instan, nasi instan, pai daging, dll.

Schaninger (1981) menunjukkan bahwa kelas sosial lebih baik untuk digunakan sebagai dasar segmentasi pasar barang tahan lama dibandingkan pendapatan. Hasil penelitian menunjukkan bahwa kelas sosial lebih unggul dibandingkan dengan pendapatan dalam segmentasi makanan dan minuman non-alkohol, serta perilaku belanja dan menonton televisi di malam hari. Pendapatan lebih unggul dari kelas sosial pada kasus barang peralatan utama, minuman ringan, dan minuman beralkohol. Kombinasi pendapatan dan kelas sosial lebih unggul untuk make-up dan pakaian, serta mobil dan kepemilikan televisi.

Elfick (2011) menyatakan bahwa konsumerisme menjadikan manusia meredefinisikan dirinya dan status sosialnya dalam konteks konsumsi dan gaya hidup. Dengan semakin meningkatkan kemampuan membeli, permintaan akan barang rumah tangga, pakaian dan makanan impor akan semakin tinggi; demikian juga halnya dengan kepemilikan mobil dan investasi kesehatan. Semakin meningkatnya pendapatan konsumen, maka akan semakin meningkat pula pengeluaran akan leisure, hiburan, dan perjalanan luar negeri (Tianjie, 2013). Menurut penelitian Mihić \& Ćulina (2006), pendapatan lebih berpengaruh pada produk-produk mahal yang mana untuk mengkonsumsinya konsumen harus mengeluarkan uang dalam jumlah banyak, sedangkan kelas sosial lebih dominan dalam mempengaruhi produk-produk yang berhubungan dengan prestige, kelihatan mahal, dan menandakan gaya hidup kelas tertentu. Sebagai contoh, dalam penelitian tersebut ditunjukkan bahwa seseorang dari kelas sosial tinggi lebih banyak mengkosumsi makanan sehat, alami, dan sederhana, sedangkan seseorang berpendapatan tinggi malah sebaliknya. Seseorang dari pendapatan rendah lebih banyak mengkonsumsi makan cepat saji sedangkan dari kelas sosial rendah lebih sedikit. Presentase pemilik mobil pada kelompok pendapatan rendah lebih banyak dibandingkan dengan kelas sosial rendah. Untuk pembelian produk-produk fashion, kelas sosial rendah lebih mempertimbangkan kualitas dari pada harga, sedangkan kelompok pendapatan rendah sebaliknya.

Kelas sosial dan pendapatan memiliki peran dalam perilaku konsumen, namun manakah yang menentukan pembelian. Paper ini didasarkan pada penelitian di Kota Malang yang bertujuan mengeksplorasi faktor kelas sosial atau pendapatan sebagai faktor penentu pembelian consumer goods dan jasa. Produk consumer goods dan jasa dibedakan menjadi 18 item pembelian yang dikelompokkan menjadi 5 jenis yaitu makanan dan minuman, pakaian, barang tahan lama, jasa investasi, dan produk lain-lain.

\section{KAJIAN TEORI}

Pada seluruh sistem sosial kemasyarakatan, kelas sosial telah ada atau terbentuk. Setiap anggota kelas sosial tertentu diikat dengan posisi sosial yang sangat terdefinisi, 
yang disebut dengan status. Kelas sosial adalah pembagian anggota masyarakat ke dalam suatu hierarki kelas yang berbeda sehingga para anggota setiap kelas secara relatif mempunyai status yang sama, dan para anggota kelas lainnya mempunyai status yang lebih tinggi atau lebih rendah (Furaiji, 2012). Kategori kelas sosial biasanya disusun dalam hierarki, yang berkisar dari status yang rendah sampai yang tinggi. Aspek hierarkis kelas sosial penting bagi para pemasar karena kelas sosial dapat mempengaruhi perilaku konsumen yang penting untuk di pertimbangkan dalam segmentasi produk. Sebagai contoh, dorongan konsumsi sebagai akibat dari bertambahnya jumlah middle class di beberapa negara mulai terasakan dampaknya bagi perekonomian. Ketika diasumsikan konsumsi adalah pendorong ekonomi, maka eksplorasi kelas sosial terhadap konsumsi menjadi sangat penting. Sebagai contoh beberapa penelitian tentang kelas menengah menunjukkan bahwa middle class menjadi pendorong ekonomi di mana jumlah konsumsi kelas sosial ini adalah sepertiga konsumsi dunia. Pernyataan ini disampaikan pada penelitian Elfick (2011) yang melihat adanya perubahan dan mobilitas kelas sosial dan konsumsi masyarakat di Kota Shenzhen, China. Negara China seperti halnya India, Brazil, Indonesia dan beberapa negara Asia Tenggara sedang mengalami peningkatan jumlah kelas sosial (Knorringa \& Guarin, 2014). Laporan dari Global Economy and Development tahun 2017 menunjukkan bahwa ada lebih dari 3.2 milyar penduduk pada akhir tahun 2016 adalah middle class, dan hampir separuhnya berada di Asia (Kharas, 2017). Kondisi di Indonesia menunjukkan bahwa $42 \%$ dari penduduk berada pada kelas sosial menengah (middle class) dengan penghasilan 60-120 juta per tahun (Deloitte Southeast Asia, 2015).

Perilaku konsumen sulit dipahami tanpa mempertimbangkan kelas sosial (Hutagalung \& Aisha, 2008; Shavitt, Duo \& Hyewon, 2016). Secara umum sudah banyak literatur yang mengelompokkan segmen pasar berbasis kelas sosial (Ciribeli \& Miquelito, 2015). Kelas sosial juga memprediksi langsung preferensi dan tipe pengalaman dan pilihan pembelian. Lebih lanjut dikatakan bahwa posisi seseorang dalam hirarki sosial memiliki pengaruh penting hampir di semua aspek kehidupan sehari-hari: di mana konsumen tinggal, apa yang dipakai, kemana mereka bepergian, belanja dan makan, apa yang dikendarai dan media apa yang dikonsumsi yang berbeda-beda (Shavitt, Duo, \& Hyewon, 2016). Dengan kata lain, semua produk yang dikonsumsi dan perilaku konsumsi konsumen individu menjadi cerminan dan dicerminkan oleh kelas sosial.

Kelas sosial adalah pembedaan penduduk atau masyarakat ke dalam kelas-kelas secara bertingkat (hierarchis) dan merefleksikan socioeconomic seserorang. Kelas sosial dan status socioeconomic sering digunakan secara bergantian karena kelas sosial dikonseptalisasikan melalui pendekatan struktural dan prosesual. Struktur kelas dianalisis menggunakan pendekatan status socioeconomic seperti pendapatan, pekerjaan dan pendidikan, sementara prosesual lebih mengeksplorasi bagaimana individu mengembangkan, mengintrepretasikan dan menunjukkan identitas kelasnya (WyattNichol, Brown, \& Haynes, 2010). Kelas sosial yang didasarkan pada pekerjaan, yang sejalan dengan pendidikan dan pendapatan, adalah skema yang sering digunakan oleh pemasar Eropa (Kamakura \& Mazzon, 2013).

Mosca dalam Damsar (2010) membedakan antara kelas yang berkuasa dan kelas yang dikuasai, antara orang kaya dan orang miskin. Namun Maliki (2010) membedakan menjadi tiga kelas atau lebih, yakni:

1. Kelas atas, kelas ini ditandai oleh besarnya kekayaan, pengaruh baik dalam sektorsektor masyarakat perseorangan ataupun umum, berpenghasilan tinggi, tingkat pendidikan yang tinggi, dan kestabilan kehidupan keluarga. 
2. Kelas menengah, kelas ini di tandai oleh tingkat pendidikan yang tinggi, penghasilan dan mempunyai penghargaan yang tinggi terhadap kerja keras, pendidikan, kebutuhan menabung dan perencanaan masa depan, serta mereka dilibatkan dalam kegiatan komunitas.

3. Kelas bawah, kelas ini biasanya terdiri dari kaum buruh kasar, penghasilannya pun relatif lebih rendah sehingga mereka tidak mampu menabung, lebih berusaha memenuhi kebutuhan langsung daripada memenuhi kebutuhan masa depan, berpendidikan rendah, dan penerima dana kesejahteraan dari pemerintah. Bahkan seorang ilmuwan yang bernama Warren (dalam Horton, 2006) merinci tiga kelas ini menjadi enam kelas yaitu:

a. Kelas atas-atas (upper-upper class) mencakup keluarga-keluarga kaya lama, yang telah berpengaruh dalam masyarakat dan sudah memiliki kekayaan yang begitu lama, sehingga orang-orang tidak lagi bisa mengingat kapan dan bagaimana cara keluarga-keluarga itu memperoleh kekayaannya.

b. Kelas atas bawah (lower upper class) mempunyai jumlah uang yang sama, tetapi mereka belum terlalu lama memilikinya dan keluarga ini belum lama berpengaruh terhadap masyarakat.

c. Kelas menengah atas (upper middle class) mencakup kebanyakan pengusaha dan orang profesional yang berhasil, yang umumnya berlatar belakang keluarga baik dan berpenghasilan yang menyenangkan.

d. Kelas menengah bawah (lower middle class) meliputi para juru tulis, pegawai kantor dan orang-orang semi profesional.

e. Kelas bawah atas (upper lower class) terdiri atas sebagian besar pekerja tetap.

f. Kelas bawah bawah (lower-lower class) meliputi para pekerja tidak tetap, penganggur, buruh musiman. Akan tetapi dalam mengkaji pembagian kelas sosial, disini penulis menitikberatkan pembagian kelas sosial menjadi tiga kelas, yakni kelas atas, menengah, dan bawah.

Perbandingan spesifikasi kategori kelas sosial dihitung berdasarkan proporsi terbesar pada income prestige dari pekerjaan (Wolff \& Zacharias, 2007). Sementara pemasar Eropa menggunakan dasar pekerjaan dalam skema stratifikasi sosial, pemasar 'dunia baru' menggunakan konsep socioeconomic status, dengan menggunakan permanent income sebagai pengukuran laten (Kamakura \& Mazzon, 2013).

Di Indonesia sendiri saat ini masih sangat sulit menemukan penelitian empiris tentang pengukuran dan hubungan kelas sosial dengan perilaku konsumsi. Dasar penentuan kelas sosial di Indonesia masih sebagian dilihat dari akar historis kolonialisme. Saat ini basis data pendapatan dari Badan Pusat Statistik (BPS) masih sering menjadi acuan kelas sosial. Oleh karena penggunaan satu basis penggolongan tidak dapat mencerminkan kelas sosial, maka penelitian ini menggunakan Index of Social Position (ISP) sebagai dasar penggolongan kelas sosial.

Kelas sosial dapat diukur menggunakan tiga teknik; 1). Pendekatan reputasional; 2). Pendekatan subyektif; 3). Pendekatan obyektif. Pendekatan reputasional dikenal dengan pendekatan Warner, bersumsi bahwa kelas sosial dapat ditentukan oleh reputasi seseorang yang disebut oleh masyarakat sekitarnya. Pendekatan subyektif, adalah pendekatan penentuan kelas sosial dari sisi individu itu sendiri. Pendekatan obyektif, mengukur kelas sosial dari basis demografi yang bebas dari bias individu. Pendekatan obyektif terbagi menjadi dua jenis yaitu yang menggunakan indeks tunggal (single factor/item index) atau yang non tunggal (multiple factors/item index). Pendekatan single item index sering 
digunakan pemasar dengan menggunakan salah satu faktor: pendapatan, pekerjaan dan pendidikan. Meski pendapatan sering digunakan dalam menentukan kelas sosial seseorang, pendapatan, disebut oleh Coleman (1983) sebagai faktor yang apabila meningkat, belum tentu atau hampir selalu tidak dapat menghasilkan perubahan dalam klas sosial keluarga. Penelitian Chaundhary dan Verma (2016) menunjukkan bahwa status sosial dapat dikaitkan dengan pekerjaan.

Pendekatan multiple items index menggunakan beberapa item dalam menentukan kelas sosial. Beberapa metode yang sering digunakan oleh peneliti adalah Warner's Index of Status Characteristic (ISC); Hollingshead Index of social position (ISP); Coleman's Computerized status index (CSI). Mengadopsi penelitian Mihić \& Ćulina (2006), penggolongan kelas sosial pada penelitian ini dibagi menjadi 3 yaitu kelas sosial atas, kelas sosial menengah, dan kelas sosial bawah menggunakan Index of Social Position $(I S P)$. Nilai ISP adalah indeks kombinasi antara pekerjaan, pendidikan, dan pendapatan keluarga, nilai dari ISP tersebut akan menentukan posisi kelas sosial. Tabel 2 menjelaskan penggolongan kelas sosial berdasarkan total nilai ISP.

Nilai ISP $=($ bobot pekerjaan $\mathrm{x} 4)+($ bobot pendidikan $\mathrm{x} 3)+($ bobot pendapatan $\mathrm{x} 3)$

Tabel 1. Index Of Sosial Position

\begin{tabular}{ll}
\hline Skala Pekerjaan (Bobot Nilai 4) & \\
\hline Deskripsi & Nilai \\
\hline Pekerja Tidak Tetap & 10 \\
Tenaga tidak terdidik (Pembantu Rumah Tangga, tukang & 9 \\
kebun, buruh serabutan, dll) & 8 \\
Petani kecil dan tidak tetap & 7 \\
Pensiunan yang hanya tergantung pada tunjangan & 6 \\
Tenaga terampil (pemotong rambut, pekerja pabrik, & \\
sekretaris, dan kelas kayawan lainnya) & 5 \\
Manjer menengah, supervisor, pemilik usaha kecil, & \\
pejabat pemerintah & 4 \\
Guru, dosen, TNI, Polisi dan PNS Lainnya & 3 \\
Tenaga Profesional kelas atas seperti Dokter, artis, & \\
seniman terkenal, pelukis terkenal, designer terkenal) & 2 \\
Manajer atas, pemilik usaha menengah (10-20 pegawai) & 1 \\
Eksekutif tinggi perusahaan, pemilik usaha besar, & \\
Pejabat Tinggi Negara (menteri, DPR, dll) & \\
Skala Pendidikan (Bobot Nilai 3) & Nilai \\
\hline Pendidikan yang sedang ditempuh atau sudah & 10 \\
ditempuh & 9 \\
\hline Tidak pernah mengenyam pendidikan & 8 \\
Sekolah Dasar (SD) & 7 \\
Sekolah Menengah Pertama (SMP) & 6 \\
Sekolah Menengah Atas / Kejuruan (SMA/SMK) & 5 \\
Diploma 1 (D1) & 4 \\
Diploma 2 (D2) & 3 \\
Diploma 3 (D3) & 2 \\
Strata 1 / Diploma 4 (S1/D4) & \\
Strata 2 (S2) & \\
\hline
\end{tabular}




\begin{tabular}{ll} 
Strata $3(\mathrm{~S} 3)$ & 1 \\
\hline Skala Pendapatan (Bobot Nilai 3) & \\
\hline Jumlah total Pedapatan per Bulan & Nilai \\
\hline s.d $1000 \mathrm{KN}$ & 10 \\
s.d $2000 \mathrm{KN}$ & 9 \\
s.d $3000 \mathrm{KN}$ & 8 \\
s.d $4000 \mathrm{KN}$ & 7 \\
s.d $6000 \mathrm{KN}$ & 6 \\
s.d $8000 \mathrm{KN}$ & 5 \\
s.d $10000 \mathrm{KN}$ & 4 \\
s.d $13000 \mathrm{KN}$ & 3 \\
s.d $16000 \mathrm{KN}$ & 2 \\
$>16000 \mathrm{KN}$ & 1 \\
\hline
\end{tabular}

Sumber: Mihić \& Ćulina (2006)

Tabel 2. Penggolongan Kelas Sosial dengan ISP

\begin{tabular}{rlc}
\hline No & \multicolumn{1}{c}{ Tingkat Kelas Sosial } & Nilai ISP \\
\hline 1 & Kelas Sosial Tinggi & $10-27$ \\
2 & Kelas Sosial Sedang & $28-60$ \\
3 & Kelas Sosial Rendah & $61-100$
\end{tabular}

Sumber: Mihić \& Culina (2006)

Kelas sosial sering dikaitkan dengan pendapatan. Hal ini terjadi karena proses pembentukan kelas sosial dalam pandangan modern berasal dari penggolongan strata pekerjaan dan jabatan yang berkorelasi dengan pendapatan. Variabel pendapatan sering disebut sebagai faktor kelas sosial, namun beberapa tulisan menempatkan pendapatan sebagai bagian dari pekerjaan dan pendidikan; artinya, pendapatan adalah konsekuensi dari pekerjaan dan pendidikan. Pendapatan dan kelas sosial sering dipisah dan digabung dalam berbagai penelitian. Namun Mihić \& Ćulina (2006) sendiri menyatakan bahwa sejak fenomena kelas sosial dalam pemasaran menjadi subyek studi, sebagian besar riset mempertimbangkan kelas sosial sebagai variable daripada pendapatan.

Menurut penelitian Mihić \& Culina (2006), pendapatan lebih berpengaruh pada produk-produk mahal yang mana untuk mengkonsumsinya konsumen harus mengeluarkan uang dalam jumlah banyak, sedangkan kelas sosial lebih dominan dalam mempengaruhi produk-produk yang berhubungan dengan prestige, kelihatan mahal, dan menandakan gaya hidup kelas tertentu. Sebagai contoh, dalam penelitian tersebut ditunjukkan bahwa seseorang dari kelas sosial tinggi lebih banyak mengkosumsi makanan sehat, alami, dan sederhana, sedangkan seseorang berpendapatan tinggi malah sebaliknya. Seseorang dari pendapatan rendah lebih banyak mengkonsumsi makan cepat saji sedangkan dari kelas sosial rendah lebih sedikit. Presentase pemilik mobil pada kelompok pendapatan rendah lebih banyak dibandingkan dengan kelas sosial rendah. Untuk pembelian produk-produk fashion, kelas sosial rendah lebih mempertimbangkan kualitas dari pada harga, sedangkan kelompok pendapatan rendah sebaliknya.

Pendapatan adalah jumlah penghasilan yang diterima oleh keluarga dalam periode setiap bulan.Variabel pendapatan yang sering digunakan dalan berbagai studi adalah gross household money income (Wolff \& Zacharias, 2007) sama seperti Badan statistik USA 
yang menggunakan pretax money income (Meyer \& Sullivan, 2011), namun Wolff dan Zacharias sendiri menggunakan ukuran comprehensive income dalam penelitiannya. Badan Pusat Statistik (BPS) menggolongkan pendapatan masyarakat menjadi dua, yaitu penduduk miskin dan penduduk tidak miskin. BPS menggunakan konsep kemampuan memenuhi kebutuhan dasar (basic need approach) dalam mengukur kemiskinan. Dengan pendekatan ini, kemiskinan dipandang sebagai ketidakmampuan dari sisi ekonomi untuk memenuhi kebutuhan dasar makanan dan bukan makanan yang diukur dari sisi pengeluaran.

Penduduk miskin adalah mereka yang pendapatannya dibawah Garis Kemiskinan (GK), sedangkan tidak miskin yang pendapatannya diatas garis kemiskinan. Penghitungan GK adalah Garis Kemiskinan Makanan (GKM) ditambah dengan Garis Kemiskinan Non Makan (GKNM). GKM adalah jumlah rupiah minimum yang dibutuhkan untuk memenuhi kebutuhan pokok minimum makanan yang setara dengan 2100 kilokalori per kapita per hari. GKNM adalah kebutuhan pokok bukan makanan meliputi perumahan, sandang, pendidikan, dan kesehatan (BPS, 2013). Sementara itu penelitian Deloitte Southeast Asia (2015) menggolongkan pendapatan konsumen sebagai proxi kelas sosial ke dalam empat tingkatan yaitu:

1. Higher income (> Rp.120 juta per tahun)

2. Upper middle income (Rp. 60-120 juta per tahun)

3. Lower middle income (Rp. 36-60 juta per tahun)

4. Lower income (<Rp. 36 Juta per tahun)

Pendapatan memiliki hubungan yang positif terhadap barang normal, sedangkan barang inferior memiliki hubungan yang negatif terhadap pendapatan karena jika kenaikan pendapatan maka permintaan terhadap barang inferior akan menurun. Dengan menganggap pendapatan tetap sebenarnya tidak dapat ditafsirkan bahwa pendapatan tidak mempunyai pengaruh terhadap jumlah barang yang diminta, karena masih ada faktorfaktor lain yang juga tidak kurang penting yaitu barang lain dan selera (Mankiw, 2008).

Konsumsi memiliki arti yang penting dalam mengekspresikan identitas sosial (Elfick, 2011). Hutagalung \& Aisha (2008) menyebutkan bahwa salah satu faktor yang dapat mempengaruhi perilaku konsumen adalah kelas sosial. Konsumsi dapat berarti suatu ekspresi dari karakteristik kelas sosial tertentu (Al-Modaf, n.d). Hubungan antara kelas sosial dengan konsumsi adalah self-reflexive. Kelas sosial mempengaruhi pola konsumsi sehingga dengan demikian sebaliknya konsumsi merefleksikan suatu status sosial (AlModaf, n.d). Sebagai contoh penelitian menunjukkan bahwa prebedaan klas sosial berkaintan dengan konsumsi dan pilihan seluruh jenis makanan (Hupkens, Knibbe, \& Drop, 2000). Kelas sosial juga terbukti menjadi indicator penting yang terkait dengan 8 produk sehari-hari konsumen (Mihić dan Ćulina, 2006).

Schaninger (1981) menyatakan bahwa kelas sosial lebih baik untuk digunakan sebagai dasar segmentasi pasar barang tahan dibandingkan pendapatan. Hasil penelitian menunjukkan bahwa kelas sosial lebih unggul dibandingkan dengan pendapatan dalam segmentasi makanan dan minuman non-alkohol, serta perilaku belanja dan menonton televisi di malam hari. Pendapatan lebih unggul dari kelas sosial pada kasus barang peralatan utama, minuman ringan, dan minuman beralkohol. Kombinasi pendapatan dan kelas sosial lebih unggul untuk make-up dan pakaian, serta mobil dan kepemilikan televisi.

Penelitian Myers, Stanton, \& Haug (1971), membandingkan korelasi antara kelas sosial dan pendapatan terhadap perilaku konsumen khusus pada barang-barang kebutuhan sehari-hari yang relatif murah. Penelitian ini menunjukkan bahwa pendapatan lebih 
dominan dalam mempengaruhi perlaku konsumen dalam kasus barang kebutuhan seharihari dalam bentuk kemasan dibandingkan kelas sosial. Kelas sosial itu sendiri lebih dominan dalam mempengaruhi produk-produk yang berhubungan dengan kenyamanan atau cara praktis seperti mie instan, nasi instan, pai daging, dll.

\section{Hipotesis}

Ha 1: Ada hubungan antara pendapatan dan kelas sosial dengan pembelian consumer goods dan jasa

\section{METODE}

Jenis penelitian ini merupakan penelitian survey yaitu untuk mendapatkan data dari tempat tertentu yang alamiah. Penelitian ini juga termasuk dalam penelitian ex-post facto, yaitu suatu penelitian yang dilakukan untuk meneliti peristiwa yang telah terjadi. Dilihat dari jenis data dan pendekatan analisisnya, penelitian ini termasuk dalam jenis penelitian kuantitatif. Berdasarkan eksplanasinya, penelitian initermasuk dalam penelitian komparatif, yaitu membandingkan kelas sosial dan pendapatan. Populasi penelitian ini sebanyak 100 responden dari 100 keluarga yang mewakili penduduk Kota Malang, tersebar di seluruh kecamatan (5 kecamatan). Teknik pengumpulan data menggunakan purposive sampling. Responden harus memiliki pekerjaan, pendapatan tetap, dan memiliki KTP Kota Malang. Variabel yang digunakan di dalam penelitian ini adalah Kelas Sosial (X1) dan Pendapatan (X2). Variabel kelas sosial (X1) dan pendapatan (X2) kemudian diasosiasikan dengan pembelian consumer goods dan jasa diadopsi dari Mihić \& Ćulina (2006). Namun beberapa barang dan jasa tidak sesuai dengan karakteristik tempat penelitian. Barang dan jasa yang tidak sesuai disesuaikan dengan kelompok barang menurut BPS. Setelah pengembangan dan perubahan tersebut, terdapat kelompok barang dan jasa berjumlah 18 instrumen penelitian yang telah sesuai dengan karakteristik tempat penelitian, kedelapan belas instrumen tersebut adalah:

\section{Food and Beverages}

a. Frekuensi membeli atau mengkonsumsi daging

b. Tempat membeli daging

c. Frekuensi mengkonsumsi susu

d. Jenis susu yang dikonsumsi

e. Frekuensi mengkonsumsi soft drink

f. Frekuensi mengkonsumsi fast food

g. Jenis fast food yang dikonsumsi

\section{Clothing}

h. Rata-rata harga baju yang dibeli

i. Tempat pembelian baju

\section{Durable Goods}

j. Jenis transportasi yang digunakan

k. Harga rata-rata kendaraan pribadi

1. Peralatan elektronik rumah tangga yang dimiliki

m. Peralatan elektronik pribadi yang dimiliki

n. Harga alat komunikasi khususnya handphone yang dimiliki

4. Various Types of Services

o. Jenis fasilitas investasi dan keuangan yang dimiliki 
p. Jumlah nilai investasi dan keuangan yang dimiliki

\section{Other}

q. Status kepemilikan tempat tinggal dan bangunan

r. Harga tempat tinggal dan bangunan

\section{HASIL DAN PEMBAHASAN}

Data yang ada di dalam penelitian ini merupakan data yang sudah diuji validitasnya dengan analisis korelasi pearson dengan nilai diatas 0,1638 dan reliabilitasnya menggunakan Cronbach's Alpha dengan nilai sebesar 0,943. Sehingga dapat dikatakan bahwa data yang digunakan dalam penelitian ini secara statistik memenuhi syarat untuk dianalisis lebih lanjut untuk dilakukan uji chi-square.

Tabel 3. Deskripsi Responden

\begin{tabular}{|c|c|c|}
\hline No & Indikator & $\begin{array}{c}\text { Presentase } \\
(\%)\end{array}$ \\
\hline & Jenis Kelamin & \\
\hline 1 & Laki-laki & $56 \%$ \\
\hline \multirow[t]{2}{*}{2} & Perempuan & $44 \%$ \\
\hline & Usia & \\
\hline 1 & $21-30$ th & $31 \%$ \\
\hline 2 & $31-40$ th & $50 \%$ \\
\hline 3 & $41-50$ th & $14 \%$ \\
\hline \multirow[t]{2}{*}{4} & $51-60$ th & $5 \%$ \\
\hline & Tingkat Pendapatan (dalam Rupiah) & \\
\hline 1 & Pendapatan Tinggi $\geq 19.000 .001$ & $16 \%$ \\
\hline 2 & Pendapatan Sedang 7.600.001 - 19.000.000 & $33 \%$ \\
\hline \multirow[t]{2}{*}{3} & $\begin{array}{l}\text { Pendapatan Rendah } \leq 7.600 .000 \\
\text { *berdasar UMK saat penelitian Rp. } 1.900 .000\end{array}$ & $51 \%$ \\
\hline & Pendapatan & \\
\hline 1 & $>30.400 .000$ & $4 \%$ \\
\hline 2 & 24.700.001-30.400.000 & $4 \%$ \\
\hline 3 & 19.000.001-24.700.000 & $8 \%$ \\
\hline 4 & 15.200.001-19.000.000 & $10 \%$ \\
\hline 5 & $11.400 .001-15.200 .000$ & $10 \%$ \\
\hline 6 & 7.600.001-11.400.000 & $13 \%$ \\
\hline 7 & $5.700 .001-7.600 .000$ & $15 \%$ \\
\hline 8 & $3.800 .001-5.700 .000$ & $13 \%$ \\
\hline 9 & $1.900 .001-3.800 .000$ & $17 \%$ \\
\hline \multirow[t]{2}{*}{10} & $\leq 1.900 .000$ & $6 \%$ \\
\hline & Pendidikan & \\
\hline 1 & Tidak Sekolah & $0 \%$ \\
\hline 2 & $\mathrm{SD}$ & $0 \%$ \\
\hline 3 & SMP & $5 \%$ \\
\hline
\end{tabular}




$\begin{array}{clr}4 & \text { SMA/SMK } & 23 \% \\ 5 & \text { Diploma 1 (D1) } & 13 \% \\ 6 & \text { Diploma 2 (D2) } & 8 \% \\ 7 & \text { Diploma 3 (D3) } & 11 \% \\ 8 & \text { S1/D4 } & 38 \% \\ 9 & \text { Strata 2 (S2) } & 2 \% \\ 10 & \text { Strata 3 (S3) } & 0 \%\end{array}$

Jenis Pekerjaan Persentase

1 Eksekutif tinggi perusahaan, pemilik usaha besar, $\quad 9 \%$ pejabat tinggi $\quad 9 \%$

2 Manajer atas, pemilik usaha menengah (10-20 19\%

$3 \quad$ Tenaga profesional kelas atas $\quad 7 \%$

4 Guru, dosen, TNI, Polisi dan PNS Lainnya $14 \%$

$5 \quad$ Manajer menengah, supervisor, pemilik usaha kecil, $\quad 21 \%$

6 Tenaga terampil dan kelas kayawan lainnya $28 \%$

7 Pensiunan yang hanya tergantung pada tunjangan $1 \%$

8 Petani kecil dan tidak tetap $1 \%$

9 Tenaga tidak terdidik $\quad 0 \%$

10 Pekerja Tidak Tetap $0 \%$

Tingkat Kelas Sosial

$1 \quad$ Kelas Sosial Tinggi ISP $10-27 \quad 11 \%$

2 Kelas Sosial Sedang ISP 28-60 54\%

3 Kelas Sosial Rendah ISP $61-100 \quad 35 \%$

Tabel 4. Perbedaan Nilai Chi square Kelas Sosial dan Pendapatan

\begin{tabular}{rlccccc}
\hline No & \multicolumn{1}{c}{ Kategori } & $\begin{array}{c}\text { Kelas } \\
\text { Sosial }\end{array}$ & Sig & $\begin{array}{c}\text { Pendapat- } \\
\text { an }\end{array}$ & Sig & Selisih \\
\hline & \multicolumn{1}{c}{ Makanan dan Minuman } & & & & & \\
1 & Frekuensi membeli daging sapi & 37.837 & Sig & 47.136 & Sig & 9.299 \\
2 & Tempat membeli daging sapi & 29.981 & Sig & 52.504 & Sig & 22.523 \\
3 & Frekuensi mengkonsumsi susu & 28.285 & Sig & 28.681 & Sig & 0.396 \\
4 & Jenis susu yang dikonsumsi & 12.921 & Not Sig & 18.743 & Sig & 5.822 \\
5 & $\begin{array}{l}\text { Frekuensi mengkonsumsi soft } \\
\text { drink }\end{array}$ & 38.493 & Sig & 42.443 & Sig & 3.950 \\
6 & $\begin{array}{l}\text { Frekuensi mengkonsumsi fast } \\
\text { food }\end{array}$ & 46.960 & Sig & 26.593 & Sig & 20.367 \\
7 & $\begin{array}{l}\text { Jenis fast food yang dikonsumsi } \\
\quad \text { Pakaian }\end{array}$ & 44.466 & Sig & 35.816 & Sig & 8.650 \\
8 & $\begin{array}{l}\text { Rata-rata harga baju yang dibeli } \\
\text { per potong }\end{array}$ & 39.481 & Sig & 32.957 & Sig & 6.524
\end{tabular}


Triwijayati dan Pradipta: Kelas Sosial VS Pendapatan: Eksplorasi Faktor Penentu:...

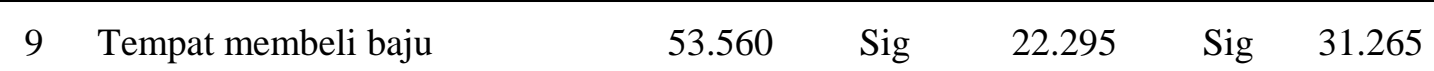

\section{Barang tahan lama}

10 Jenis transportasi yang digunakan $\quad 51.433 \quad$ Sig $\quad 66.808 \quad$ Sig $\quad 15.375$

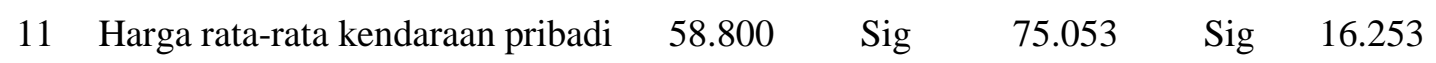

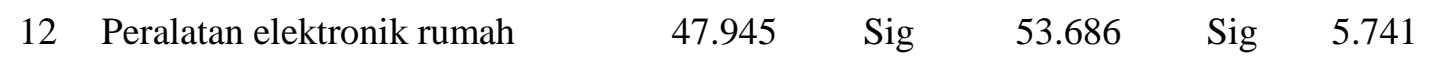
tangga yang dimiliki

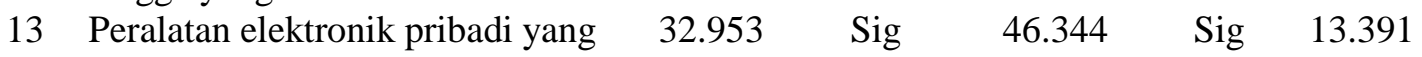
dimiliki

14 Rata-rata harga elektronik pribadi $\quad \begin{array}{llllll}50.024 & \text { Sig } & 38.854 & \text { Sig } & 11.170\end{array}$

\section{Investasi}

15 Jenis fasilitas jasa investasi dan keuangan yang dimiliki

$39.990 \quad$ Sig $\quad 49.981 \quad$ Sig $\quad 9.991$

16 Jumlah nilai investasi dan $\quad 103.991 \quad$ Sig $\quad 79.720 \quad$ Sig $\quad 24.271$

keuangan yang dimiliki

Rumah dan bangunan

17 Kepemilikan tempat tinggal dan bangunan lain

$18 \quad$ Harga kepemilikan tempat $\quad 39.991 \quad$ Sig $\quad 56.253 \quad$ Sig $\quad 16.262$ tinggal dan bangunan lain

\section{Makanan dan minuman}

1. Konsumsi daging sapi masih berkaitan erat dengan pendapatan dan kelas sosial, meski secara umum faktor pendapatan masih lebih menentukan pembelian daging sapi. Namun seiring dengan tingginya pendapatan, tempat pembelian daging sapi bergeser ke pasar-pasar modern. Andini, Lubis, \& Ayu (2013) menunjukkan terdapat hubungan antara pendapatan dengan konsumsi yang salah satunya adalah produk daging dimana hal tersebut berbanding lurus yang berarti semakin tinggi pendapatan maka semakin tinggi pula konsumsi daging yang dilakukan. Selain itu menurut Muskananfola (2013) kemampuan seseorang dalam membeli produk sangat bergantung pada kemampuan finansial yang dimiliki daripada selera dan kelas sosial. Tempat pembelian daging sangat mempengaruhi harga dan kualitas daging yang dibeli. Kualitaas daging yang berada di mall/ departement store sangat terjaga kualitasnya karena dibungkus dengan baik dan ditempatkan pada suhu tertentu agar tetap segar. Bagi mereka yang memiliki pendapatan yang lebih tinggi memiliki kemampuan yang lebih baik dari kelas sosial, karena kelas sosial tertentu belum menjamin tingginya pendapatan. Hal tersebut juga disampaikan oleh Bahar (2012) menunjukkan bahwa tempat pembelian daging masih terkait kemampuan daya beli masyarakat yang dilihat dari income atau pendapatan mereka. Bagi mereka yang memiliki pendapatan yang lebih mampu membeli dan mengakses produk yang berkualitas salah satunya adalah produk daging.

2. Konsumsi susu tidak terlalu berkaitan dengan kelas sosial dan pendapatan. Kelas sosial hanya berkaitan dengan frekuensi konsumsi susu dan tidak berkaitan dengan jenis susu yang dikonsumsi; sedangkan faktor pendapatan berkaitan dengan frekuensi dan jenis susu yang dikonsumsi. Hal tersebut diperkuat oleh Retnaningsih, Dwiriani, \& Kurniati (2008) menunjukkan bahwa tingkat kelas sosial yang tinggi berbanding lurus dengan 
tingkat pendidikan/ pengeteahuan mengenai manfaat susu sehingga mempengaruhi frekuensi mengkonsumsi susu pada masing-masing orang. Demikian juga pendapat Hidayanti (2005) bagi mereka yang memiliki pendapatan yang lebih tinggi mengkonsumsi susu bukanlah hal yang luar biasa, mereka selalu melakukan belanja bulanan atau mingguan dan salah satu produk yang dibelinya adalah susu yang merupakan kebutuhan.

Jenis susu yang ada dipasaran sangat beragam tergantung kualitas yang dimiliki serta sistem pengolahannya. Menurut pendapat Antari (2008) menjelaskan bahwa pendapatan dan tingkat pendidikan seseorang memberikan dampak pada jenis produk yang dikonsumsi, semakin tinggi pendapatan dan pendidikan mereka maka mereka akan lebih selektif dalam memilih produk karena hal tersebut menyangkut pemeliharaan kualitas hidupnya. Salah satu produk yang cukup selektif untuk dibeli sesuai dengan pendapatan mereka antara lain jenis makanan seperti makanan yang organik dan jenis susu yang lebih segar. Berdasarkan kajian tersebut terlihat bahwa mereka yang memiliki pendapatan yang tinggi lebih selektif daripada mereka yang memiliki pendapatan yang lebih rendah.

3. Konsumsi soft drink sama-sama berkaitan dengan kelas sosial dan pendapatan konsumen, pendapatan memiliki hubungan yang lebih tinggi dibandingkan dengan kelas sosial. Hasil tersebut menunjukkan bahwa kelas sosial yang didalamnya terdapat unsur pembentuk yang terdiri dari pendapatan, pendidikan, dan pekerjaan. Pendidikan cukup memberikan kontribusi seseorang untuk tidak mengkonsumsi soft drink sehingga kelas sosial memiliki hubungan yang lebih rendah jika dibandingkan dengan pendapatan karena belum tentu pendapatan yang tinggi memiliki pendidikan dan pengetahuan yang tinggi pula khususnya yang berkaitan dengan pemilihan makanan dan minuman. Hal tersebut sesuai dengan pendapat Saputri (2013) menunjukkan hasil bahwa semakin tinggi tingkat pengetahuan seseorang maka tingkat konsumsi soft drink semakin rendah, sedangkan dengan tingkat pengetahuan rendah atau kurang maka semakin tinggi tingkat konsumsi soft drink. Tingkat pengetahuan ini berbanding lurus dengan kelas sosial, semakin tinggi kelas sosial maka pengetahuannya tentang soft drink maka semakin tinggi pula.

4. Kelas sosial dan pendapatan konsumen juga berkaitan positif dengan frekuensi pembelian fastfood; namun faktor kelas sosial berhubungan lebih erat dengan tingkat keseringan konsumsi fastfood. Atau dengan kata lain semakin tinggi kelas sosial memiliki kecenderungan lebih sering mengkonsumsi fastfood. Hal tersebut sesuai dengan pendapat Primadini \& Budiani (2014) yang menjelaskan bahwa kelas sosial seseorang memiliki hubungan yang berbanding lurus dengan prestige dan gaya hidup yang dijalaninya. Fast food merupakan jenis makanan siap saji yang identik dengan restoran kelas atas, bagi mereka yang memiliki kelas sosial tinggi dan memiliki gaya hidup tinggi memandang mengkonsumsi fast food sebagai bentuk aktualisasi dari gaya hidupnya. Kelas sosial seseorang memiliki hubungan yang berbanding lurus dengan prestige dan gaya hidup yang dijalaninya. Seseorang yang memiliki status yang lebih tinggi akan memilih restoran seperti Mc Donald, KFC atau Pizza Hut dibandingkan dengan memilih jenis fast food pada restoran yang lebih rendah.

\section{Pakaian}


1. Kelas sosial dan pendapatan sama-sama berkaitan erat dengan harga baju dan tempat pembelian baju. Semakin tinggi kelas sosial dan pendaptan, semakin tinggi frekuensi pembelian baju. Namun tempat membeli baju lebih berkaitan dengan kelas sosial konsumen; dengan kata lain semakin tinggi kelas sosial, konsumen akan cenderung memilih tempat membeli baju yang lebih nyaman dan modern.

Harga baju yang lebih mahal tentunya memiliki kualitas yang lebih bagus. Pakaian atau baju merupakan salah satu icon atau simbol yang dapat menunjukkan kelas sosial seseorang sehingga bagi kalangan sosial tertentu harga dan kualitas baju menjadi perhatian khusus untuk menunjukkan esistensi diri mereka. Hal tersebut sesuai dengan pendapat Ulkhusna (2015) bahwa kelas sosial berpengaruh positif dengan keputusan pembelian baju batik pada masyarakat dimana untuk kelas sosial atas lebih memilih pakaian yang lebih mahal dan berkualitas daripada kelas sosial rendah.

Tempat membeli baju yang berbeda akan menampilkan produk yang berbeda dan kualitas yang berbeda. Bagi mereka yang memiliki kelas sosial yang lebih tinggi akan memilih tempat yang terkenal seperti butik khusus agar mereka dapat membeli barangbarang yang bermerek dan diproduksi terbatas. Hal tersebut sesuai yang dikemukakan oleh Aditia (2012) yang menjelaskan bahwa budaya, kelas sosial, kelompok acuan kecil, keluarga, pengalaman, kepribadian, sikap dan keyakinan, sangat berpengaruh kepuasan dalam memilih tempat dan kualitas pakaian. Sedangkan untuk pendapatan juga memiliki hubungan namun masih kalah jika dibandingkan dengan kelas sosial, hal ini dikarenakan bahwa pendapatan yang besar tidak menunjukkan pengaruh yang tinggi terhadap kegiatan mengkonsumsi produk fashion.

\section{Barang Tahan lama}

1. Kelas sosial dan pendapatan juga menentukan jenis dan harga moda transprotasi yang dipilih. Namun pendapatan konsumen lebih menentukan jenis transportasi yang lebih nyaman dan harga rata-rata kendaraan yang lebih tinggi. Hal ini sejalan dengan penelitian Tianjie (2011) bahwa pembelian kendaraan pada kelas sosial mayoritas tidak menunjukkan status namun lebih tentang practical purchase. Murti (2015) menjelaskan bahwa bagi mereka yang memiliki pemasukan atau pendapatan yang lebih tinggi yang berasal dari pekerjaannya tentunya memiliki mobilitas yang lebih tinggi pula. Kemampuan mobilitas seseorang sangat ditentukan oleh jenis kendaraan seseorang, bagi mereka yang memiliki pendapatan yang lebih besar akan menginginkan kendaraan yang cepat dan nyaman tentunya. Jenis kendaraan yang mahal dan mewah menjadi alternatif pilihan utama bagi mereka karena dengan begitu selain membantu mobilitas juga memiliki aspek kenyamanan dan keamanan yang lebih tinggi. Alimuddin (2013) menjelaskan bahwa bagi mereka kalangan ekonomi atas yang memiliki penghasilan di atas rata-rata pendapatan nasional di negara-negara maju memiliki kecenderungan membeli kendaraan yang lebih mahal dan selalu mengganti kendaraan tersebut jika terdapat seri atau model baru.

2. Pendapatan dan kelas sosial sama-sama berkaitan erat dengan kepemilikan alat-alat elektronik. Pendapatan lebih menentukan kepemilikan alat elektronik pribadi dan rumah tangga, namun kelas sosial lebih berkaitan dengan harga peralatan elektronik pribadi. Artinya adalah semakin tinggi kelas sosial, semakin tinggi harga alat elektronik pribadi yang dimiliki.

Resal (2013) yang menjelaskan bahwa pemilihan dan kelengkapan barang elektronik sangat dipengaruhi oleh tingkat pendapatan seseorang, semakin tinggi pendapatan 
maka semakin beragam barang elektronik yang dimiliki. Studi pada masyarakat kelas sosial menengah di Shenzhen menunjukkan bahwa semakin sejahtera konsumen, semakin kuat kecenderungan untuk menata rumah tinggal dan kelengkapannya secara modern dan simple. Gaya hidup simple (simple life) mendorong konsumsi dekorasi dan peralatan elektronik yang memudahkan pekerjaan rumah tangga (Elfick, 2011).

Binder (2013) menunjukkan bahwa kepemilikan peralatan elektronik pribadi merupakan suatu hal yang sangat strategis, namun hal tersebut bukan berarti semua masyarakat wajib memiliki karena terkendala dengan harga dan kebutuhan pada pekerjaannya, jika dalam pekerjaannya membutuhkan peralatan elektronik yang memadai maka bisa dipastikan orang tersebut harus memiliki peralatan tersebut untuk menunjang pekerjaannya.

Harga barang elektronik pribadi sangat dipengaruhi oleh kelas sosial jika dibandingkan dengan pendapatan hal tersebut sesuai dengan pendapat penelitian Latifah (2013) bahwa masyarakat dalam golongan sosial ekonomi yang cukup tinggi dapat membeli handphone dengan harga yang relatif mahal serta kcenderungan memiliki handphone lebih dari satu. Kepemilikan handphone dengan harga ynag tinggi ini disebabkan karena adanya gengsi atau prestige sebagai alat komunikasi sehari-hari.

Investasi. Kelas sosial dan pendapatan sama-sama berkaitan erat dengan jenis dan jumlah investasi yang dimiliki. Perbedaannya adalah bahwa pendapatan lebih berkaitan dengan jenis atau ragam investasi sedangkan kelas sosial berkaitan dengan nilai investasi.

Pendapatan lebih memiliki hubungan yang tinggi jika dibandingkan dengan kelas sosial karena dengan pendapatan yang lebih tinggi maka sesorang dapat membeli berbagai macam investasi sedangkan bagi kelas sosial tertentu akan memilih fokus pada salah satu jenis investasi namun memiliki kualitas dan harga yang lebih bagus. Hal tersebut sesuai dengan pendapat dengan Anoraga (2011) bahwa jenis fasilitas investasi dan keuangan beragam jenisnya, pilihan investasi yang bagus adalah investasi jangka panjang minimal 5 tahun dan jangka waktu menengah dengan rentang $1-5$ tahun, semakin lama waktu investasinya, semakin tinggi tingkat pendapatannya, karena hal ini terkait langsung dengan pendapatan orang tersebut.

Kelas sosial memiliki hubungan yang lebih tinggi jika dibandingkan dengan pendapatan karena kepemilikan jumlah nilai investasi tergantung pada kelas sosial orang tersebut. Penelitian Tianjie (2013) menunjukkan bahwa kelas konsumen menengah menyimpan sampai dengan $30 \%$ penghasilannya, lebih besar daripada konsumen kelas bawah $(5-10 \%)$ dari penghasilan. Konsumen Indonesia yang berpenghasilan lebih dari Rp 5 Juta per bulan cenderung bergeser dari pembelian produk pokok menuju produk suplementer misalnya credit card, liburan, dan tabungan atau investasi (Deloitte Southeast Asia, 2015).

Rumah tinggal. Pendapatan dan kelas sosial berkaitan erat dengan kepemilikan dan harga rumah tinggal; namun secara umum pendapatan konsumen menjadi faktor yang lebih menentukan harga rumah tinggal yang dimiliki atau dibeli. Status kepemilikan tempat tinggal dan bangunan merupakan salah satu kepemilikan yang terbilang cukup mahal untuk dimiliki, sehingga masyarakat membutuhkan biaya yang cukup tinggi dalam memiliki status kepemilikan tempat tinggal dan bangunan ini lebih dari satu. Tingkat pendapatan mempengaruhi masyarakat dalam status kepemilikan tempat tinggal dan bangunan. Status kepemilikan tempat tinggal dan bangunan disesuaikan dengan segmen 
kelas ekonomi, yaitu kelas atas, menengah serta bawah (Rahadian dalam Anastasia, 2013). Pendapatan lebih memiliki hubungan yang tinggi jika dibandingkan dengan kelas sosial karena masyarakat membutuhkan biaya yang cukup tinggi dalam memiliki dengan harga tempat tinggal dan bangunan lebih dari satu. Tingkat pendapatan mempengaruhi masyarakat dalam memiliki tempat tinggal dan bangunan. Hal tersebut sesuai dengan hasil penelitian Yahya, Husna, \& Qodriyah (2013) bahwa tingkat pendapatan sangat berpengaruh dalam pemilihan tempat tinggal. Sikap dan pandangan seseorang dalam memilih kriteria hunian tergantung pada tingkat pendapatan, sering kali masyarakat dengan ekonomi tertentu akan memilih jenis hunian dan lokasi yang sesuai dengan kemampuan finansial mereka, semakin tinggi tingkat pendapatan seseirang semakin mahal juga pemilihan dalam tempat tinggal tersebut.

\section{PENUTUP}

Penelitian ini bertujuan untuk menguji hubungan antara kelas sosial dan pendapatan dengan pembelian consumer goods dan jasa di Kota Malang, adapun simpulan dari penelitian ini antara lain:

a. Kelas sosial memiliki hubungan yang berbanding lurus dengan pembelian goods dan jasa dilihat dari 18 komponen penelitian, hanya jenis susu yang dikonsumsi yang tidak memiliki hubungan positif dengan pembelian goods dan jasa. Artinya semakin tinggi kelas sosial, semakin tinggi tingkat konsumsinya atau lebih baik kualitasnya.

b. Kelas sosial dan pendapatan berkaitan dengan pemeblian makanan dan minuman kecuali jenis susu hanya berkaitan dengan tingkat pendapatan. Secara umum pendapatan lebih berkaitan dengan pembelian daging, susu dan soft drink dan kelas sosial lebih berkaitan dengan pembelian fastfood.

c. Kelas sosial dan pendapatan berkaitan positif dengan pembelian pakaian, di mana kelas sosial lebih menentukan harga dan tempat pembelian pakaian.

d. Kelas sosial dan pendapatan memiliki hubungan positif dengan pembelian bahan tahan lama yakni jenis dan harga alat transportasi, serta jenis dan harga peralatan elektronik. Secara umum faktor pendapatan lebih menentukan pembelian barang tahan lama tersebut kecuali harga peralatan elektronik pribadi lebih ditentukan oleh kelas sosial.

e. Kelas sosial lebih menentukan jumlah atau nilai investasi, sedangkan pendapatan lebih menentukan jenis investasi yang dipilih konsumen.

f. Faktor pendapatan lebih menentukan konsumsi kepemilikan dan harga rumah tinggal.

g. Pendapatan memiliki hubungan yang positif dengan pembelian seluruh item consumer goods dan jasa. Artinya semakin tinggi pendapatan, semakin tinggi tingkat konsumsinya atau lebih baik kualitasnya.

h. Terdapat perbedaan hubungan antara kelas sosial dan pendapatan dengan pembelian consumer goods dan jasa. Kelas sosial lebih berhubungan dengan fast food, baju, harga peralatan elektronik pribadi, dan jumlah investasi dan keuangan. Sedangkan pendapatan lebih berhubungan dengan daging, susu, jenis kendaraan yang digunakan, kepemilikan alat elektronik, jenis investasi dan keuangan, dan tempat tinggal dan bangunan lain.

Penelitian ini tidak melihat perbedaan hubungan antara kelas sosial dan pendapatan, namun hanya melihat perbandingan deskriptif dari hasil uji chi square masing-masing 
hubungan. Peneliti selanjutnya disarankan melihat perbedaan antar faktor terhadap item pembelian secara bersamaan. Penelitian juga juga terbatas pada 5 jenis atau item produk yang dibeli yaitu makanan dna minuman, pakaian, barang tahan lama, jasa investasi, dan lain-lain (rumah tinggal dan bangunan). Peneliti selanjutnya dapat menambahkan produk selain yang diteliti, seperti diteliti oleh (Deloitte Southeast Asia, 2015) yaitu beverages, clothing and footwear, confectionary, household cleaning product, packaged food, personal hygiene product, and tobacco.

\section{DAFTAR RUJUKAN}

Aditia, F. (2012). "Faktor-faktor yang Mempengaruhi Keputusan Pembelian baju MINT di Counter Java Mall Semarang". Jurnal Kajian Akutansi dan bisnis, 1(1), 1-24. Retrieved from http://jurnal.widyamanggala.ac.id/index.php/wmkeb/article/view/51

Al-Modaf, O. A. (n.d.). Class and Consumption: a Comparative Analysis of Consumption patterns a Cross Different Social Classes. Retrieved June 5, 2017, from www.kau.edu.sa/Files/0003309/Files/69972_Consumption\%20and\%20Class.pdf

Alimuddin. (2013). "Analisis Faktor-faktor yang Mempengaruhi Permintaan Kendaraan Bermotor di Kota Makasar". Jurnal ilmiah Ilmu Ekonomi. Retrieved from http://repository.unhas.ac.id/handle/123456789/6028

Anastasia, N. (2013). "Peta Persepsi Konsumen terhadap Atribut Rumah Tinggal di Surabaya". Journal Management and Entrepreneurship, 15(2), 141-152. DOI: 10.9744/jmk.15.2.141-152

Andini, R., Lubis, S. N., \& Ayu, S. F. (2013). “Analisis Permintaan Daging Sapi di Kota Medan". Journal on Social Economic of Agriculture and Agribusiness, 2(2). Retrieved from http://jurnal.usu.ac.id/index.php/ceress/article/view/8069/3463

Anoraga, P. (2011). Pengantar Pasar Modal . Jakarta: Rineka Cipta.

Antari, S. (2008). "Pengaruh pendapatan, Pendidikan, dan Remiten terhadap Pengeluaran Konsumsi Pekerja Migrant Non Permanen di Kabupaten Badung". Jurnal Ekonomi Pembangunan, 4(2), 1-18. Retrieved from http://ojs.unud.ac.id/index.php/piramida/article/view/2975/2133

Bahar, B. (2012). Panduan Praktis Memilih Produk Daging Sapi. Jakarta: Gramedia Pustaka.

Badan Pusat Statistik. (2013). Data dan Informasi Kemiskinan Kabupeten/Kota 2012. Jakarta: Badan Pusat Statistik.

Binder, A. (2013). Tren Kerja dengan Alat Elektronik Pribadi. Retrieved from http://www.dw.com/id/tren-kerja-dengan-alat-elektronik-pribadi/a-16492087

Chaundhary, G., \& Verma, O. P. (2016). "a Study of the influence of extrinsic factors on consumer buying behavior". International Journal of Advanced Research of Computer and Software Engineering, 6(10), 351-357.

Ciribeli, J. P., \& Miquelito, S. (2015). "Market Segmentation by psychographic criteria: an essay on the main psychographic theoretical approaches and its relationship with performance criteria". Vision de Futuro, 19(1), 51-64.

Coleman, R. P. (1983). "The Continuing Sinificance of Social Class to Marketing". Journal of Consumer Research, 10(3), 265-280.

Damsar. (2010). Pengantar Sosiologi Politik (Revisi ed.). Jakarta: Prenada Media.

Deloitte Southeast Asia. (2015). Deloitte Consumer Insight Capturing Indonesia's Latent Market. Deloitte Southeast Asia. 
Elfick, J. (2011). “Class Formation and Consumption among Middle Class Professionals in Shenzhen". Journal of Current Chinese Affairs, 40(1), 187-211.

Furaiji, F., Latuszynska, M., \& Wawrzyniak, A. (2012). "An Empirical Study of the Factors Influencing Consumer Behavior in The Electric Appliances Market". Journal of Contemporary Economic, 6(3), 76-86. DOI: 10.5709/ce.1897-9254.52.

Hidayanti, L. (2005). Hubungan Karakteristik Keluarga dan kebiasaan Konsumsi Makanan Kariogenik dengan Keparahan Karies Gigi Anak Sekolah Dasar. Semarang: Universitas Diponegoro. Retrieved from http://eprints.undip.ac.id/8535/

Horton, P. B. (2006). Sosiologi (6 ed.). Jakarta: Erlangga.

Hutagalung, R. B., \& Aisha, N. (2008). "Analisis faktor-faktor yang Mempengaruhi Perilaku Konsumen terhadap Keputusan Menggunakan Dua Ponsel (GSM dan CDMA) pada Mahasiswa Departermen Manajemen Fakultas Ekonomi USU”. Jurnal Manajemen Bisnis, 2(3), 97-102.

Jacqueline, E. (2011). "Class Formation and Consumption among Middle-Class Professionals in Shenzhen". Journal of Current Chinese Affairs, 40(1), 187-211.

Kamakura, W. A., \& Mazzon, J. A. (2013). "Socioeconomic Status and Consumption in an Emerging Economy". International Journal of Research in Marketing, 30, 4-18.

Kharas, H. (2017). The Unprecedented Expansion of Global Middle Class. Brookings Institution. Massachusetts: Global Economy and Development.

Knorringa, P., \& Guarin, A. (2014). Standard and Consumer Behaviour of the Rising Middle Class in India. In E. Das (Ed.), Globalization and Standards Issues and Challenges in Indian Business. Springer.

Latifah, M. (2013). Blackberry dan Gaya Hidup Mahasiswa (Studi terhadap Perilaku dan Gaya Hidup Mahasiswa Jurusan Sosiologi dan Antropologi Unnes yang Menggunakan Ponsel Blackberry). Semarang: Universitas Negeri Semarang. Retrieved from http://lib.unnes.ac.id/1780/

Maliki, Z. (2010). Mkana Kekuasaan dan Transformasi Politik. Yogyakarta: Gadjah Mada University Press.

Mankiv, N. G. (2008). Principles of Macroeconomics (5 ed.). Chula Vista: South-Western College.

Meyer, B. D., \& Sullivan, J. X. (2011, September). The Material Well-Being of The Poor and the Middle Class Since 1980. Retrieved December 14, 2017, from https://www3.nd.edu/ jsulliv4/well_being_middle_class_poor4.3.pdf

Mihić, M., \& Ćulina, G. (2006). Buying Behavior and Consumption: Social Class Versus Income. Journal of Contemporary Management Issues, 11(2), 77-92. Retrieved from http://hrcak.srce.hr/index.php?id_clanak_jezik=29907\&show=clanak

Murti, G. H. (2015). "Mengurai Makna Kemacetan Ibu Kota". Jurnal Magister Kajian Sastra dan Budaya, 4(4), 40-54. Retrieved from http://journal.unair.ac.id/menguraimakna-kemacetan-ibukota-article-9646-media-161-category-8.html

Mustakanfola, I. A. (2013). "Pengaruh Pendapatan, Konsumsi dan Pemahaman Perencanaan Keuangan terhadap Proporsi Tabungan Rumah Tangga Keluarahan Tenggilis". Jurnal Manajemen Keuangan , 1(2), 61-66. Retrieved from http://studentjournal.petra.ac.id/index.php/manajemen-keuangan/article/view/1174

Myers, J. H., Stanton, R. R., \& Haug, F. (1971). Correlates of Buying Behavior: Social Class vs Income. Journal of Marketing, 35(4), 8-15. doi:10.2307/1250451

Primadini, Y., \& Budiani, M. S. (2014). "Hubungan antara Gaya Hidup dan Kelas Sosial dengan Perilaku Konsumtif pada Remaja di SMA Trimurti Surabaya”. Jurnal of 
$\begin{array}{lllll}\text { Character, } & 3(2), & \text { Retrieved } & \text { from }\end{array}$ ejournal.unesa.ac.id/article/14312/17/article.pdf

Resal, Y. B. (2013). Analisis Faktor-faktor yang Mempengaruhi Permintaan Listrik Rumah Tangga di Kota Sangatta Kalimantan Timur. Makasar: Universitas Hasanudin. Retrieved from http://repository.unhas.ac.id/handle/123456789/6631

Retnaningsih, Dwiriani, C. M., \& Kurniati, A. (2008). "Perilaku Konsumsi Susu pada Wanita Dewasa di Jakarta Timur". Jurnal Ilmu Keluarga dan Konsumen, 1(2). Retrieved from http://journal.ipb.ac.id/index.php/jikk/article/view/5155

Saputri, R. (2013). Hubungan antara Pengetahuan, Soft Drink dan Konsumsi Soft Drink dengan kejadian Obesitas pada Anak USia Remaja di SMP Budi Mulia 2 Yogyakarta. Surakarta: Universitas Muhammadiyah Surakarta. Retrieved from http://eprints.ums.ac.id/23417/

Schaninger, C. M. (1981). "Social Class Versus Income Revisited: an Empirical Investigation". Journal of marketing Research. doi:10.2307/3150954

Shavitt, S., Duo, J \& Hyewon, C. 2016. Stratification and segmentation: Social class in consumer behavior

Tianjie, H. (n.d.). China's Middle Income Consumers. Beijing: China-Britain Business Council.

Ulkhusna, R. W. (2015). Keputusan Pembelian Baju Batik Ditinjau dari Gaya Hidup dan Kelas Sosial Masyarakat Surakarta Tahun 2015. Surakarta: Universitas Muhammadiyah Surakarta. Retrieved from http://eprints.ums.ac.id/32832/

Wolff, E. N., \& Zacharias, A. (2007). Class Structure and Economic Inequality). New York: The Levy Economic Institutes.

Wyatt-Nichol, H., Brown, S., \& Haynes, W. (2010). "Social Class and Socioeconomic Status". Journal of Public Affairs Education, 17(2), 187-208.

Yahya, U., Husna, A. Z., \& Qodriyah, L. (2013). "Pengaruh Kelas Sosial Penghuni dalam Pemilihan Tenpat Tinggal terhadap Tingkat Kepuasan (Studi Kasus pada Pemukiman di Jalan Simpang Kalijaga, Sumbersari dan Comboran)". Jurnal Penelitian Pemukiman Teknik Arsitektur. Retrieved from Https://Www.Academia.Edu/5001049/Pengaruh_Kelas_Sosial_Penghuni_Dalam_P emilihan_Tempat_Tinggal_Terhadap_Tingkat_Kepuasannya. 